\title{
Stress Intensity Factors of Cracks in Solid Cylindrical Bars using ANSYS Finite Element Analysis
}

\author{
Al Emran Ismail \\ Faculty of Mechanical and Manufacturing Engineering, University Tun Hussein Onn Malaysia, Malaysia, \\ emran@uthm.edu.my.com / al_emran@hotmail.com
}

\begin{abstract}
This work presents the solution of modes I, II and III stress intensity factors (SIFs) for surface cracks in round solid bars using ANSYS WORKBENCH finite element analysis. In this software, crack models are inserted automatically into the solid bars. Several important crack variables are used such as crack depth and crack aspect ratio. Energy approach is used to obtain the stress intensity factor (SIF) along the crack fronts. Before further works, the present finite element models are verified to ensure their validity with the previously available results and found that the different between two results are relatively acceptable. Based on the numerical results, it is revealed that the roles of SIFs significantly affected by the values of crack depth and crack aspect ratio. However, it is seemed that these two important produced less effect on the mode II SIFs especially in the central region of the bars. On the other hand, for mode III SIFs, the role of crack aspect ratio and relative crack depth affected if the relative crack depth is greater than 0.2 .
\end{abstract}

Key words: Modes I, II and III stress intensity factors, ANSYS WORKBENCH, Surface crack, Round bar.

\section{INTRODUCTION}

Solid round bars are generally used to transmit power from one place to another. Sometime due to the environmental effect or material defect, the formation of cracks is unavoidable and therefore the bars experience premature failure. Then, it is very important to fully understand the behavior of these cracks when subjected to different modes of loading. For sharp defects such as crack, normally SIF or $\mathrm{J}$-integral is used to analyze the behaviors of cracks through the concept of fracture mechanics.

Nowadays, the solutions of SIFs can be found elsewhere [1-17] and the results are difficult to obtain and sometimes the required data need to be interpolated since the exact data is unavailable. Therefore, the main reason of this paper is to present a complete data for the solution of SIFs for cracks on the surface of solid round bars under tension, bending and torsion loading. This will assist researchers in this area to accelerate their research in the future. On the complete available data can be obtained from Shin and Cai [14]. However, the solutions of mode II and III is unavailable.

\section{NUMERICAL WORKS}

ANSYS WORKBENCH finite element analysis software is used to construct solid cylindrical bars and inserting the crack model to the required locations. The diameter, $D$ of the bar is $50 \mathrm{~mm}$ with the length of $150 \mathrm{~mm}$ and middle location is selected to place the cracks. There are several crack geometries are considered such as the crack depth, $a / D$ and crack aspect ratio, $a / b$ where $a$ is a minor elliptical radius and $b$ is a major elliptical radius. Parameter of $a$ is also known as crack depth. These normalized parameters are tabulation in Table 1.

Table 1: Selected values of $\mathrm{a} / \mathrm{D}$ and $\mathrm{a} / \mathrm{b}$.

\begin{tabular}{ccccccc}
\hline$a / D$ & 0.1 & 0.2 & 0.3 & 0.4 & - & - \\
\hline$a / b$ & 0.2 & 0.4 & 0.6 & 0.8 & 1.0 & 1.2 \\
\hline
\end{tabular}

Figure 1(a) shows the CAD model of the solid cylindrical model while Figure 2(b) shows the finite element model without surface cracks. Tetrahedron element is used since it is recommended for fracture analysis with an average element size is $10 \mathrm{~mm}$. Before inserting cracks, an appropriate position is selected in this case, the middle location is along the cylindrical length is considered. Considering the crack geometry as tabulated in Table 1, the crack is constructed automatically as in Figure 2(a) and the generated mesh with crack as in Figure 2(b). For a closed view, Figure 3(a) shows the aerial view of surface crack while Figure 3(b) depicts the enlarged view of surface crack. The crack is assumed to take semi-elliptical shapes while the crack front is composed of 20 divisions and the largest contour around the crack front is 0.5 $\mathrm{mm}$ with the number of circumferential is 16 . In this work, the maximum number of mesh contour is 6 or depend on the convergence of the values of SIFs. The SIFs are calculated for 20 nodes along the crack front. Before further analysis, the values of SIFs are as below:

$$
\begin{aligned}
& F_{I}=\frac{K_{I}}{\sigma \sqrt{\pi a}} \\
& F_{I I}=\frac{K_{I I}}{\tau \sqrt{\pi a}} \\
& F_{I I I}=\frac{K_{I I I}}{\tau \sqrt{\pi a}}
\end{aligned}
$$


Where $F_{I}$ is a normalized mode I SIF, $K_{I}$ is a mode I SIF and $\sigma$ is the stress due to the applied force or moment. In these cases, there are two type of stresses (tension and bending stresses) as described below, respectively.

$$
\begin{gathered}
\sigma_{a}=\frac{P}{A} \\
\sigma_{b}=\frac{M y}{I}
\end{gathered}
$$

$$
\tau=\frac{T R}{J}
$$

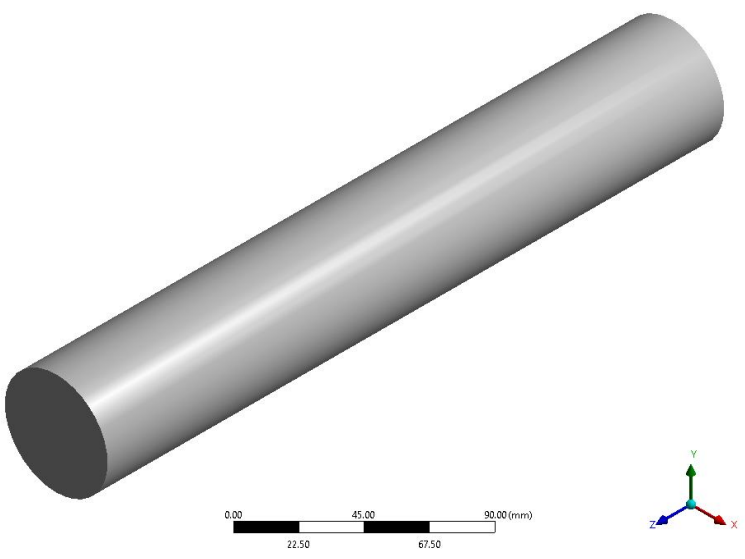

(a)

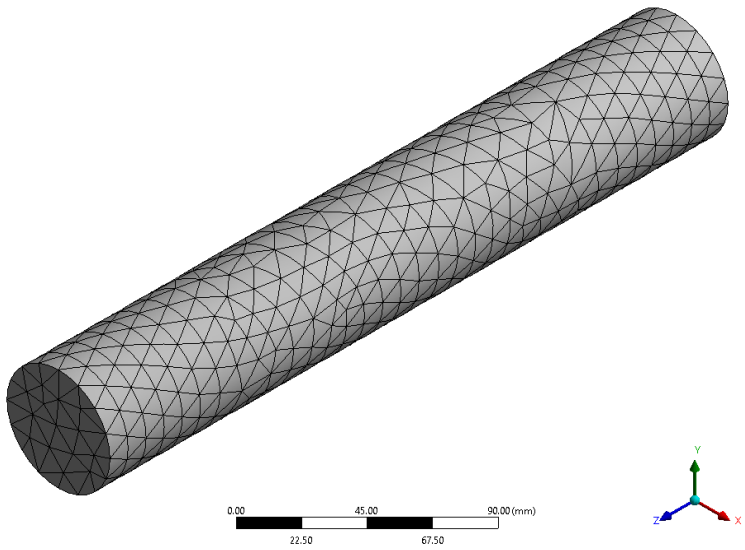

(b)

Figure 1: (a) CAD model and (b) Finite element mode for solid cylindrical bars.

Where $P$ is an applied force and $M$ is an applied moment, $\sigma_{a}$ is tension stress, $\sigma_{b}$ is a bending stress and $\tau$ is a shear stress. In order to ensure the finite element model is sufficient enough to be used, it is very important to verify their validations with the previous work. The comparison of these models is tabulated in Table 2. It is indicated that this model is relatively significantly agreed with the previous works with acceptable margin of errors. Figure 4 depicts the area of crack shape on the surface of cylindrical bar. Crack geometry can be described as major and minor radiuses, $a$ and $b$, respectively. Variable $a$ is also known as the deepest crack depth or point $c$. The most outer crack is a point $e$ and point $d$ is a point along the crack front. The position of this point can be normalized as $x / h$.

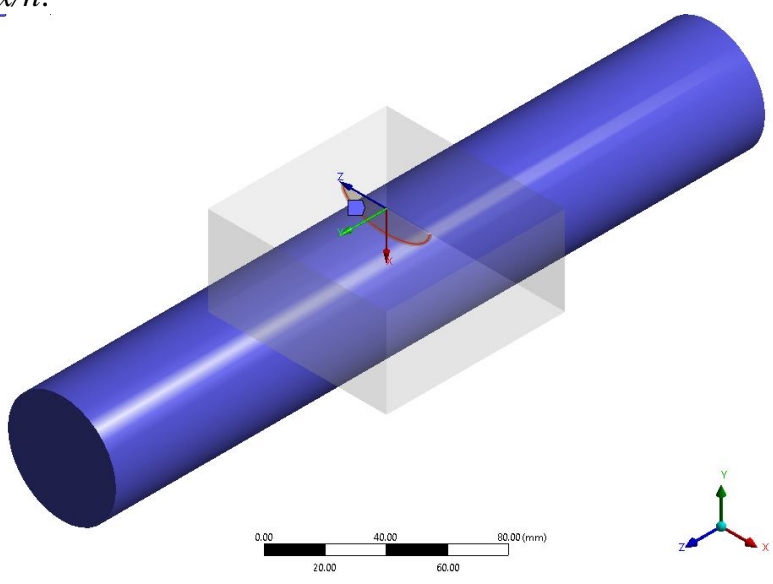

(a)

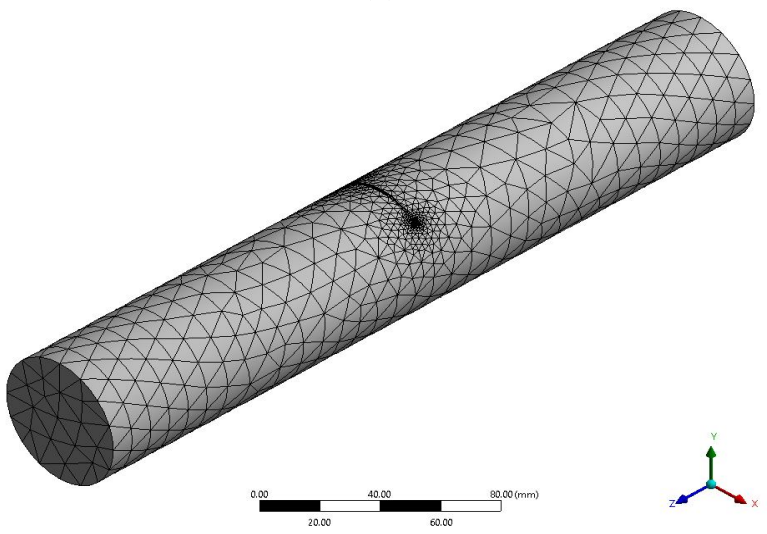

(b)

Figure 2: (a) CAD model and (b) Finite element mode for solid cylindrical bars.

Table 2: Comparison of mode I SIFs under bending moments.

\begin{tabular}{|c|c|c|c|c|c|c|}
\hline \multirow{2}{*}{$\mathrm{a} / \mathrm{D}$} & \multicolumn{3}{|c|}{$\mathrm{a} / \mathrm{b}=0.2$} & \multicolumn{3}{c|}{$\mathrm{a} / \mathrm{b}=0.4$} \\
\cline { 2 - 7 } & Present & $\begin{array}{c}\text { Shin \& } \\
\text { Cai } \\
{[14]}\end{array}$ & $\begin{array}{c}\text { Error } \\
(\%)\end{array}$ & Present & $\begin{array}{c}\text { Shin \& } \\
\text { Cai } \\
{[14]}\end{array}$ & $\begin{array}{c}\text { Error } \\
(\%)\end{array}$ \\
\hline 0.1 & 0.8973 & 0.8700 & 3.1 & 0.8311 & 0.8340 & -0.3 \\
\hline 0.2 & 0.8495 & 0.8480 & 0.2 & 0.7880 & 0.7830 & 0.6 \\
\hline 0.3 & 0.8699 & 0.8590 & 1.3 & 0.8073 & 0.7900 & 2.2 \\
\hline 0.4 & 0.9710 & 0.9640 & 0.7 & 0.8896 & 0.8880 & 0.2 \\
\hline & & $\mathrm{a} / \mathrm{b}=0.6$ & & & \multicolumn{3}{c|}{$\mathrm{a} / \mathrm{b}=0.8$} & \\
\cline { 2 - 8 } $\mathrm{a} / \mathrm{D}$ & Present & $\begin{array}{c}\text { Shin \& } \\
\text { Cai } \\
{[14]}\end{array}$ & $\begin{array}{c}\text { Error } \\
(\%)\end{array}$ & Present & $\begin{array}{c}\text { Cai } \\
{[14]}\end{array}$ & $\begin{array}{c}\text { Error } \\
(\%)\end{array}$ \\
\hline 0.1 & 0.7421 & 0.7390 & 0.4 & 0.6559 & 0.6490 & 1.1 \\
\hline 0.2 & 0.7006 & 0.6900 & 1.5 & 0.6079 & 0.5920 & 2.7 \\
\hline 0.3 & 0.7097 & 0.7160 & -0.9 & 0.5962 & 0.5920 & 0.7 \\
\hline 0.4 & 0.6921 & 0.7670 & -9.8 & 0.6338 & 0.6210 & 2.1 \\
\hline
\end{tabular}




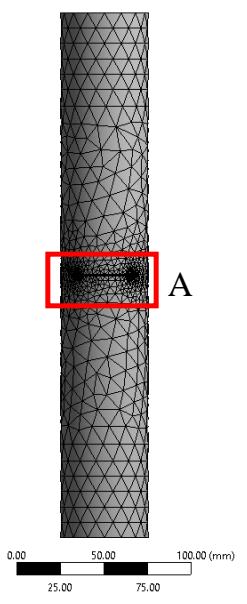

(a)

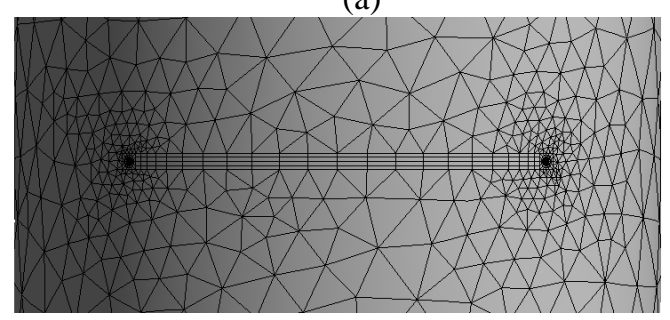

(b)

Figure 3: (a) An aerial view of surface crack and (b) An enlarged area of A of surface crack.

Table 3: Comparison of mode I SIFs under tension forces.

\begin{tabular}{|c|c|c|c|c|c|c|}
\hline \multirow[b]{2}{*}{$\mathrm{a} / \mathrm{D}$} & \multicolumn{3}{|c|}{$\mathrm{a} / \mathrm{b}=0.4$} & \multicolumn{3}{|c|}{$\mathrm{a} / \mathrm{b}=0.6$} \\
\hline & Present & $\begin{array}{c}\text { Shin \& } \\
\text { Cai } \\
{[14]}\end{array}$ & $\begin{array}{l}\text { Erro } \\
\mathrm{r}(\%)\end{array}$ & Present & $\begin{array}{c}\text { Shin \& } \\
\text { Cai } \\
{[14]}\end{array}$ & $\begin{array}{l}\text { Erro } \\
\text { r (\%) }\end{array}$ \\
\hline 0.1 & 0.9542 & 0.9650 & -1.1 & 0.8553 & 0.8590 & -0.4 \\
\hline 0.2 & 1.0568 & 1.0440 & 1.2 & 0.9438 & 0.9260 & 1.9 \\
\hline 0.3 & 1.2671 & 1.3600 & -6.8 & 1.1246 & 1.1900 & -5.5 \\
\hline 0.4 & 1.6539 & 1.6330 & 1.3 & 1.4329 & 1.4180 & 1.0 \\
\hline \multirow[b]{2}{*}{$\mathrm{a} / \mathrm{D}$} & \multicolumn{3}{|c|}{$\mathrm{a} / \mathrm{b}=0.8$} & \multicolumn{3}{|c|}{$\mathrm{a} / \mathrm{b}=1.0$} \\
\hline & Present & $\begin{array}{c}\text { Shin \& } \\
\text { Cai } \\
{[14]}\end{array}$ & $\begin{array}{l}\text { Erro } \\
\mathrm{r}(\%)\end{array}$ & Present & $\begin{array}{c}\text { Shin \& } \\
\text { Cai } \\
{[14]}\end{array}$ & $\begin{array}{l}\text { Erro } \\
\text { r (\%) }\end{array}$ \\
\hline 0.1 & 0.7591 & 0.7540 & 0.7 & 0.6763 & 0.6620 & 2.2 \\
\hline 0.2 & 0.8255 & 0.8040 & 2.7 & 0.7235 & 0.6980 & 3.7 \\
\hline 0.3 & 0.9587 & 0.8830 & 8.6 & 0.8142 & 0.8310 & -2.0 \\
\hline 0.4 & 1.1913 & 1.1700 & 1.8 & 0.9709 & 0.9440 & 2.9 \\
\hline
\end{tabular}

\section{RESULTS AND DISCUSSION}

The objective of paper is to present the solutions of SIF for modes I, II and III of surface cracks in round solid cylindrical bars. Three different type of loading are used such as bending moment and tension force. These two force/moment produced only mode I SIFs as presented in Figures 5 and 6. Figures 5 and 6 show the distributions of SIFs along the crack fronts for different crack geometries under bending moments. Based on the observations, it is found that the distribution pattern for mode I SIFs are almost similar regardless under bending moment or tension force.

For the case of $\mathrm{a} / \mathrm{b}<0.8$, the maximum SIFs occurred around the deepest point along the crack front. On the other hand, for the case of $a / b>0.8$, the maximum SIFs occurred in the region close to the outer surface. This is due to the fact that the $\mathrm{a} / \mathrm{b}>0.8$, the length of crack mount is less than the crack depth thus producing higher cross-sectional area compared with the case of $\mathrm{a} / \mathrm{b}<0.8$.

Considering the crack propagation processes, for the crack geometries of $a / b>0.8$, the maximum SIFs occurred at the most outer surface then these cracks propagate to take a semi-elliptical shape thus fulfilling the case of $\mathrm{a} / \mathrm{b}<0.8$.

Considering the surface cracks experienced torsion moments, two type of SIFs are produced such as modes II and III. These SIFs are occurred simultaneously. Figure 7 shows the mode II SIFs for different relative crack depth, a/D values. It is seemed that mode II SIFs only play a significant role in the region around the outer surface. This is probably due to at the outer surface regions, the cracks can be easily deformed as compared with the crack situated in the central region.

The role of crack geometries on the distributions of mode III SIFs can be revealed in the Figure 8. For relatively shallow cracks $(\mathrm{a} / \mathrm{D}=0.1)$, the maximum values of mode III SIFs are always occurred around the central regions for all cases of crack aspect ratios, $a / b$. These behaviors are contradicted with the patter of mode I SIFs where the role of SIFs depend on the values of $a / b$. However, the effect of $a / b$ seem to play $a$ significant role when the relative crack depth, a/D increased where the pattern of mode III is controlled by the values of $a / b$. This is due to the fact that for higher number of $a / D$, lower value of remaining ligament or cross-sectional areas thus the deformation of the bars can take place easily. Details of modes I, II and III SIFs for surface crack in round cylindrical bars can be found in appendices 1-4.

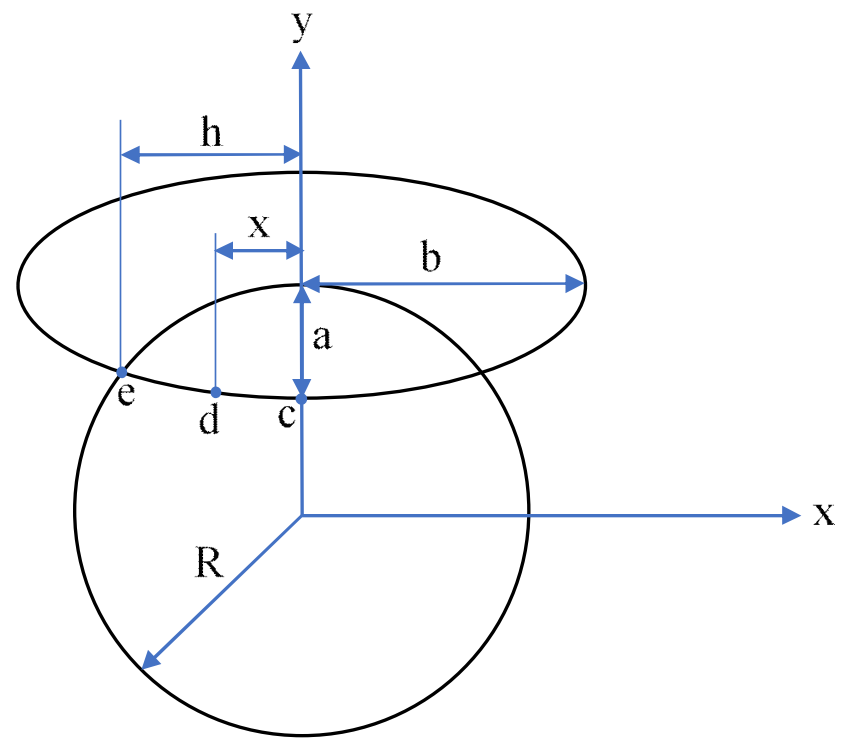

Figure 4: Crack geometry on the cross-sectional area of cylindrical bar. 
Al Emran Ismail, International Journal of Emerging Trends in Engineering Research, 8(4), April 2020, 1395 - 1404

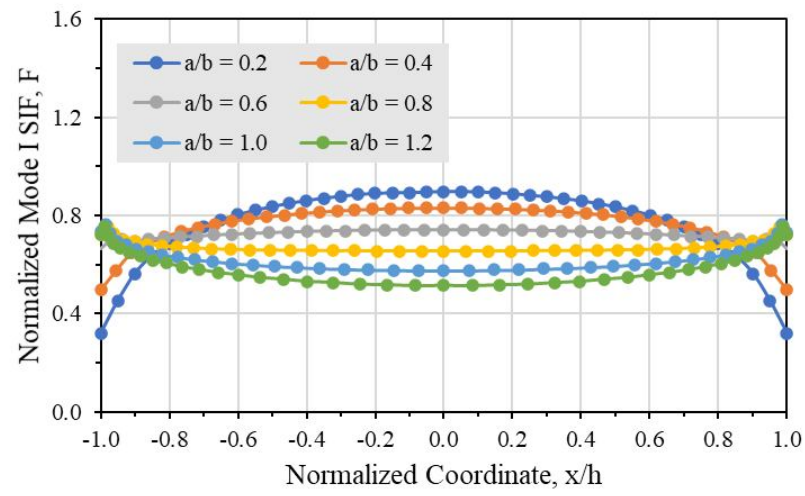

(a)

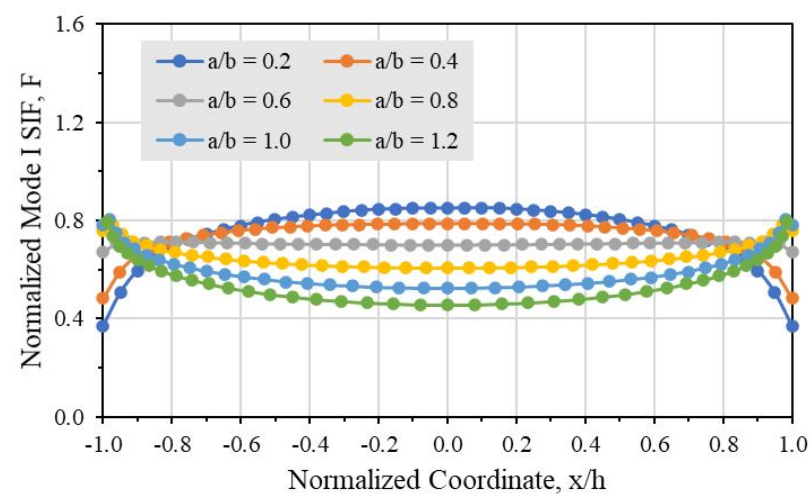

(b)

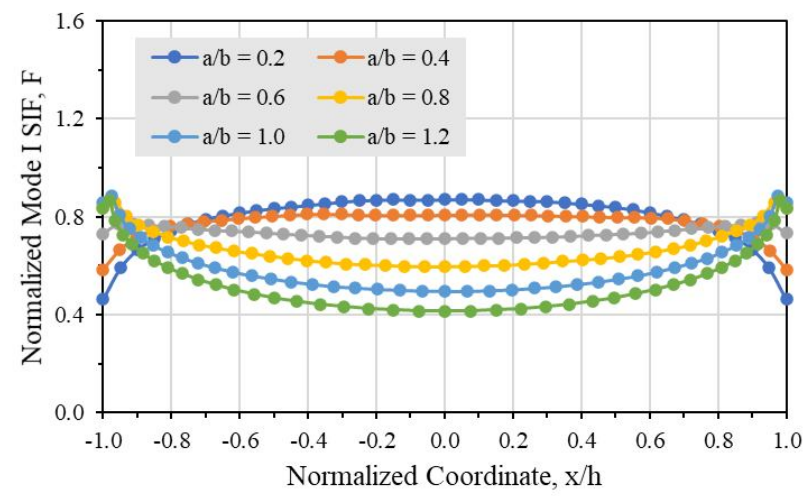

(c)

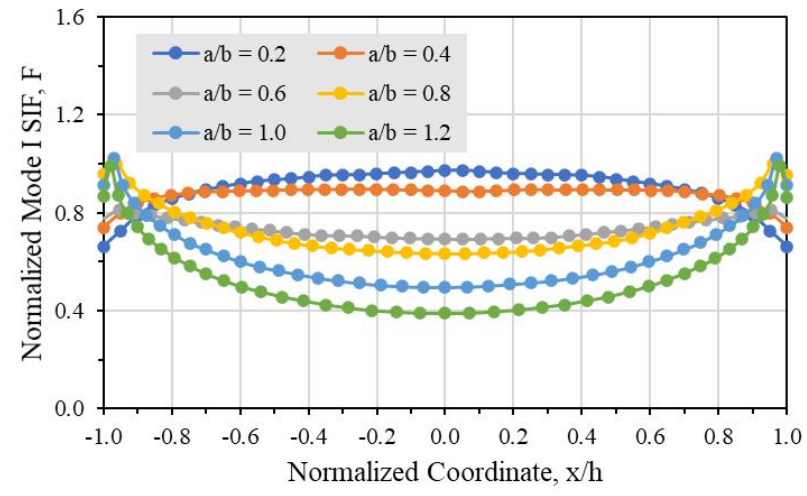

(d)

Figure 5: Mode I SIFs under bending moment for different values of a/D (a) 0.1, (b) 0.2 , (c) 0.3 and (d) 0.4 .

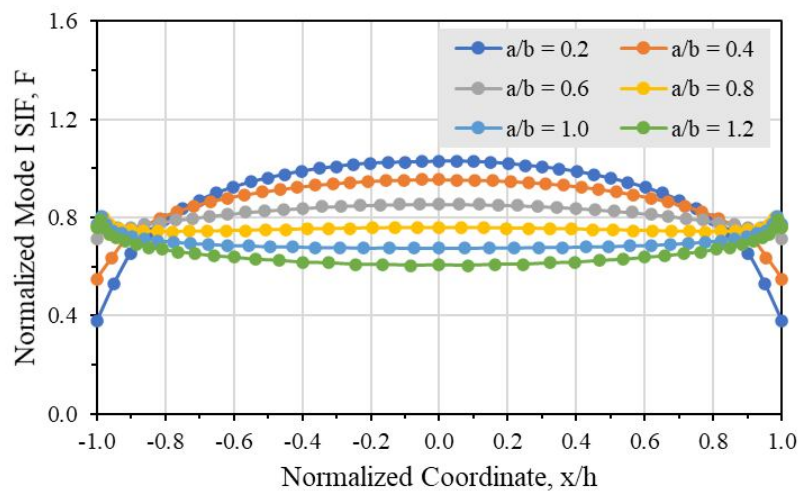

(a)

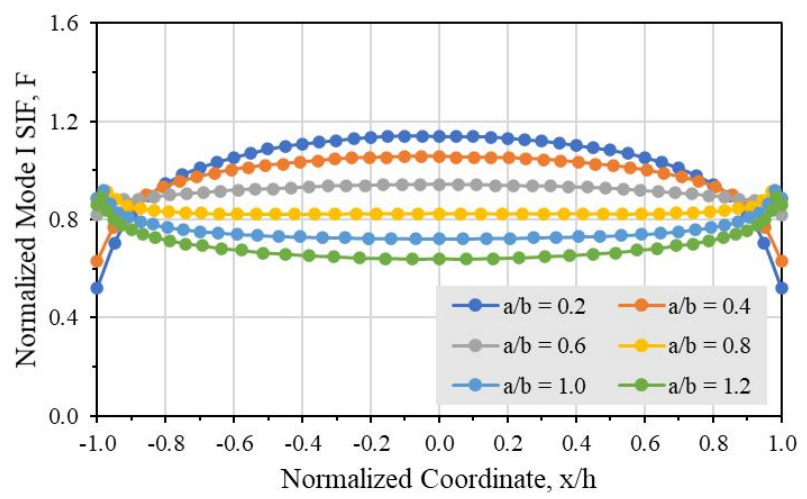

(b)

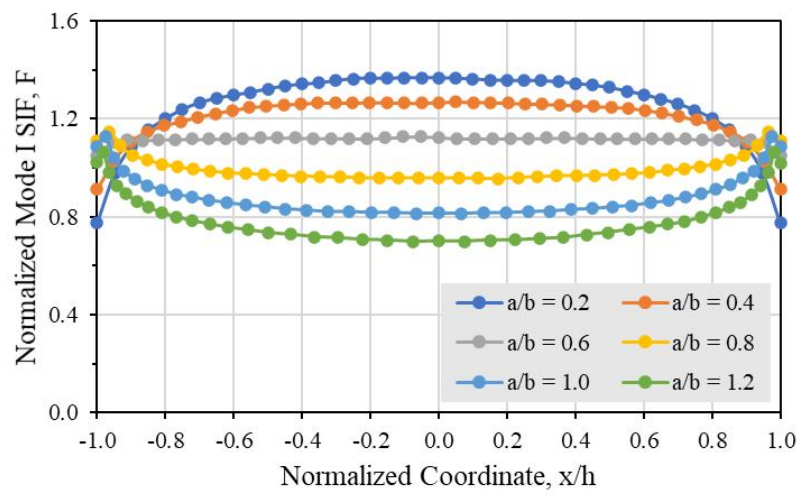

(c)

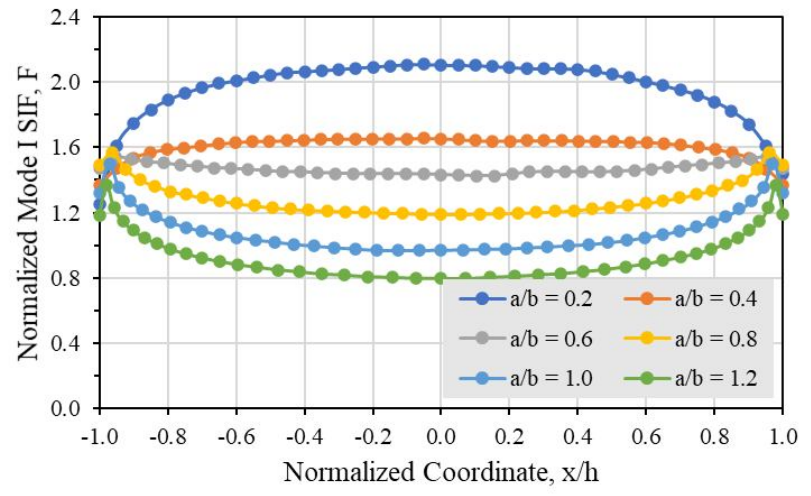

(d)

Figure 6: Mode I SIFs under tension force for different values of a/D (a) 0.1, (b) 0.2, (c) 0.3 and (d) 0.4 . 
Al Emran Ismail, International Journal of Emerging Trends in Engineering Research, 8(4), April 2020, 1395 - 1404

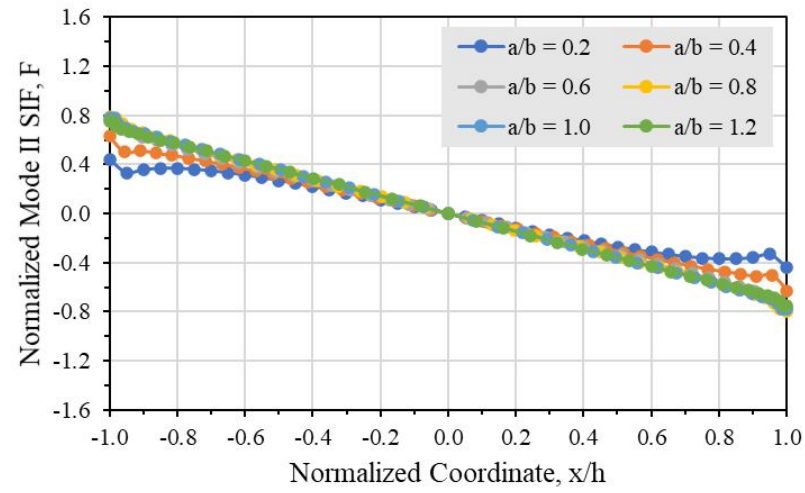

(a)

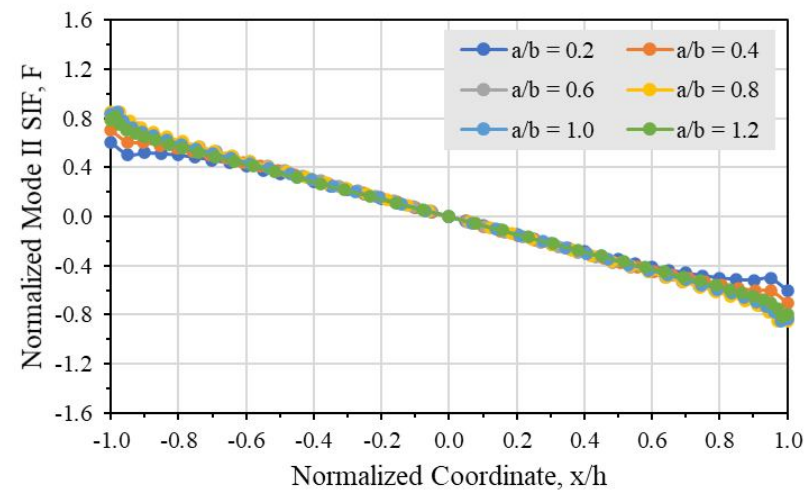

(b)

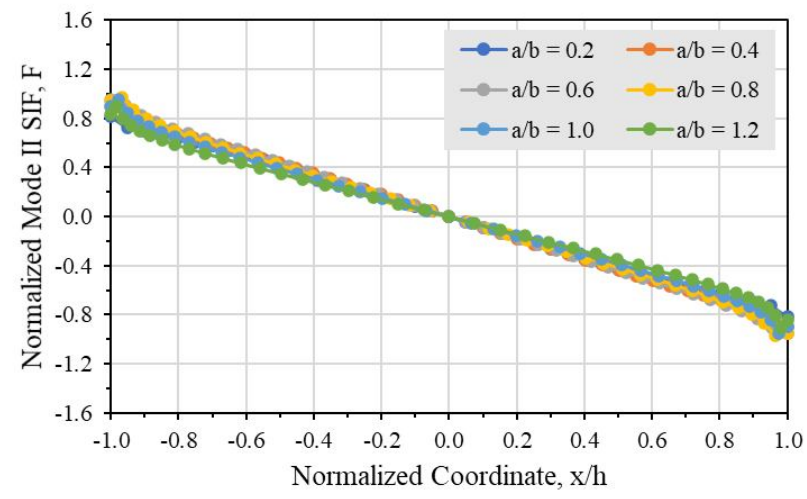

(c)

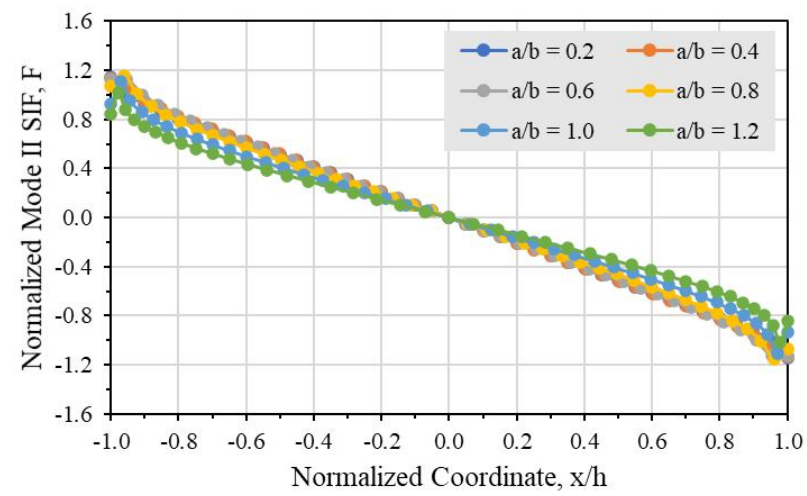

(d)

Figure 7: Mode II SIFs under torsion moment for different values of a/D (a) 0.1 , (b) 0.2 , (c) 0.3 and (d) 0.4 .

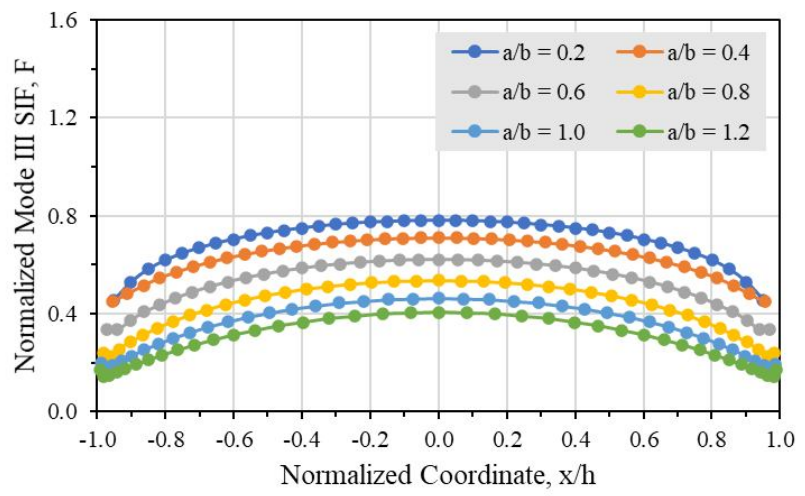

(a)

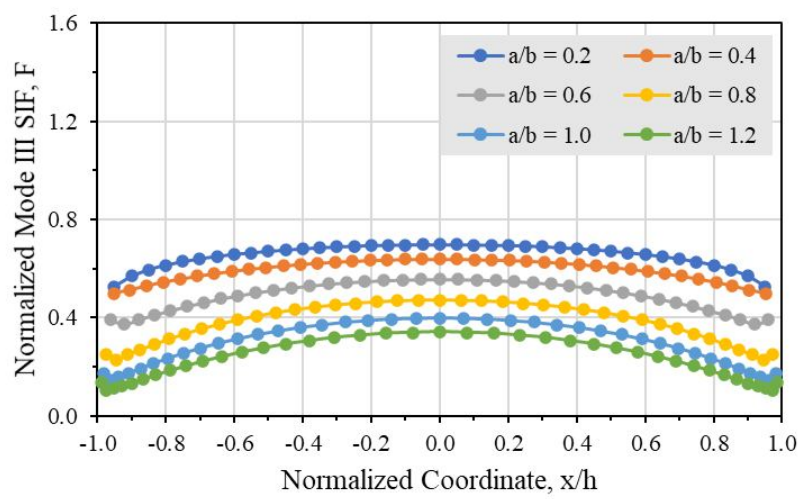

(b)

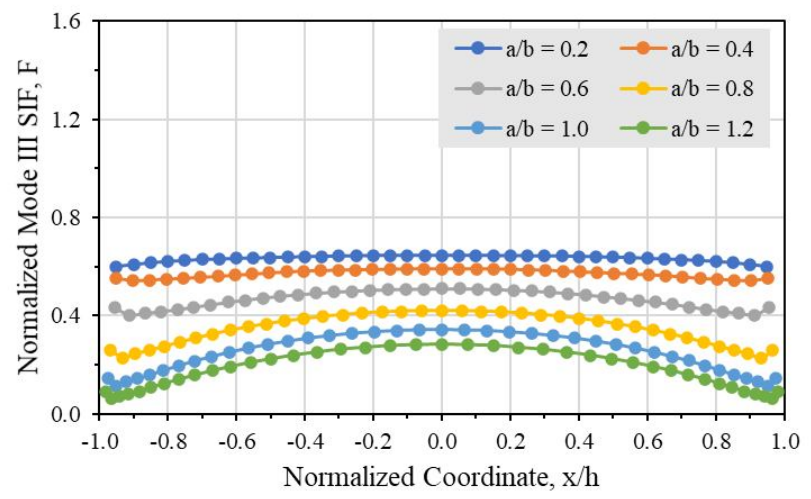

(c)

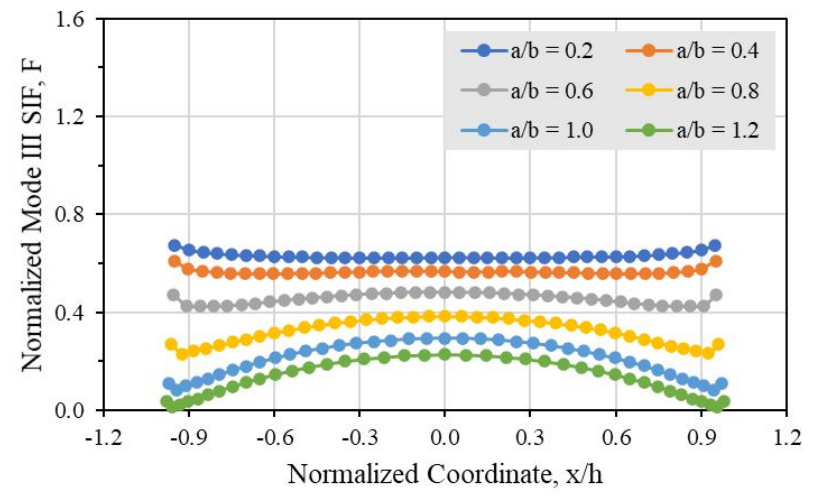

(d)

Figure 8: Mode III SIFs under torsion moment for different values of a/D (a) 0.1 , (b) 0.2 , (c) 0.3 and (d) 0.4 . 


\section{CONCLUSION}

The size of crack played important roles in determining a structural integrity of engineering materials and structures containing cracks. In general, Linear Elastic Fracture Mechanics (LEFM) is used to investigate the cracks and the stress intensity factor (SIF) is used to replace the traditional stress. The intention of this paper is to present the complete solutions of modes I, II and III stress intensity factors of surface crack in round solid cylindrical bars. The bars containing cracks are individually subjected to bending moment, tension force and torsion moment. Then, the SIFs are extracted from the nodes along the crack fronts. It can be concluded that the shape of cracks determines the level of structure integrity of engineering structures.

\section{ACKNOWLEDGEMENT}

Authors acknowledge the financial support to Research Fund E15501, Research Management Centre, Universiti Tun Hussein Onn Malaysia.

\section{REFERENCES}

[1] X.B Lin, R.A Smith. Shape growth simulation of surface cracks in tension fatigue round bars, International Journal of Fatigue, vol. 19, pp. 461-469, 1997.

https://doi.org/10.1016/S0142-1123(97)00012-1

[2] I.S Raju, J.C Newman, Stress intensity factors for circumferential surface cracks in pipes and rods under tension and bending loads. Fracture Mechanics: ASTM Special Technical Publication 905, No 17, pp 789-805, 1986. https://doi.org/10.1520/STP17428S

[3] Y. Murakami, H. Tsuru. Stress intensity factor handbook. Pergamon, New York, 1987.

[4] A. Carpinteri. Elliptical-arc surface cracks in round bars. Fatigue and Fracture of Engineering Materials and Structures, vol. 15, pp. 1141-1153, 1992. https://doi.org/10.1111/j.1460-2695.1992.tb00039.x

[5] M.D Fonte, M.D Freitas. Stress intensity factor for semi-elliptical surface cracks in round bars under bending and torsion. International Journal of Fatigue, vol. 21, pp. 457-463, 1999. https://doi.org/10.1016/S0142-1123(98)00090-5

[6] A. Carpinteri, R. Brighenti, S. Vantadori. Surface crack in notched round bars under cyclic tension and bending. International Journal of Faituge, vol. 28, pp. 251-260, 2006. https://doi.org/10.1016/j.ijfatigue.2005.05.006

[7] Y.J Kim, J.S Kim, D.J Shim, Y.J Kim, Applicability of reference stress based J estimates to semi-elliptical surface crack problems. Journal of Strain Analysis, vol. 39, pp. 245-260, 2004.

[8] A.E Ismail, A.K Ariffin, S. Abdullah, M.J Ghazali, R. Daud. Mode III stress intensity factors of surface crack in round bars, Advanced Materials Research, vol. 214, pp. 192-196, 2011.
[9] A.E Ismail, A.K Ariffin, S. Abdullah, M.J Ghazali. Finite element analysis of J-integral for surface cracks in round bars under combined mode I loading, International Journal of Integrated Engineering, vol. 9, pp. 1-8, 2017.

[10] A.E Ismail, A.L.M Tobi, N.H.M Nor. Stress intensity factors of slanted cracks in round bars subjected to mode I tension loading, AIP Conference Proceedings, vol. 1660, 070027, 2015. https://doi.org/10.1063/1.4915745

[11]A.E Ismail. Multiple crack interactions in Bi-Material plates under mode I tension loading, vol. 629, pp. 57-61, 2014.

[12] A.E Ismail, A.K Ariffin, S. Abdullah, M.J Ghazali. Stress intensity factors for surface cracks in round bars under combined bending and torsion loadings, vol. 4, pp. 827-832, 2010.

[13] A.E Ismail. Stress intensity factors of three parallel edge cracks under bending moments, IOP Conference Series: Materials Science and Engineering, vol. 50, $012020,2013$. https://doi.org/10.1088/1757-899X/50/1/012020

[14] C.S Shin, C.Q Cai. Experimental and finite element analyses on stress intensity factors of an elliptical surface crack in a circular shaft under tension and bending, International Journal of Fracture, vol. 129, pp. 239-264, 2004.

[15] A.E Ismail, A.K Ariffin, S. Abdullah, M.J Ghazali. Stress intensity factors under mode III loading, International Review of Mechanical Engineering, vol. 7, pp. 578-582, 2013.

[16] Al Emran Ismail, Abdul Fatah Mat Beyi. A brief of sources of injury and failure during stent implantation. International Journal of Emerging Trends in Engineering Research, vol. 8, pp. 667-672, 2020. https://doi.org/10.30534/ijeter/2020/10832020

[17]Agus Dwi Anggono, Nanang Ernawan, Tri Widodo Besar Riyadi. Analysis of Mechanical and Metallographic Properties on The Joining Between Aluminum and Brass by Using The Brazing Method. International Journal of Emerging Trends in Engineering Research, vol. 8, pp. 440-446, 2020. https://doi.org/10.30534/ijeter/2020/31822020 
Al Emran Ismail, International Journal of Emerging Trends in Engineering Research, 8(4), April 2020,1395 - 1404

Appendix 1: Mode I stress intensity factors under bending moment.

\begin{tabular}{|c|c|c|c|c|c|c|c|c|c|c|c|}
\hline \multicolumn{12}{|c|}{ Crack aspect ratios, a/b } \\
\hline \multicolumn{2}{|c|}{0.2} & \multicolumn{2}{|c|}{0.4} & \multicolumn{2}{|c|}{0.6} & \multicolumn{2}{|c|}{0.8} & \multicolumn{2}{|c|}{1.0} & \multicolumn{2}{|c|}{1.2} \\
\hline $\mathrm{F}$ & $\mathrm{x} / \mathrm{h}$ & $\mathrm{F}$ & $\mathrm{x} / \mathrm{h}$ & $\mathrm{F}$ & $\mathrm{x} / \mathrm{h}$ & $\mathrm{F}$ & $\mathrm{x} / \mathrm{h}$ & $\mathrm{F}$ & $\mathrm{x} / \mathrm{h}$ & $\mathrm{F}$ & $\mathrm{x} / \mathrm{h}$ \\
\hline \multicolumn{12}{|c|}{$\mathrm{a} / \mathrm{D}=0.1$} \\
\hline 0.8973 & 0.00 & 0.8311 & 0.00 & 0.7421 & 0.00 & 0.6559 & 0.00 & 0.5768 & 0.00 & 0.5156 & 0.00 \\
\hline 0.8960 & 0.10 & 0.8299 & 0.10 & 0.7416 & 0.12 & 0.6561 & 0.13 & 0.5785 & 0.15 & 0.5186 & 0.16 \\
\hline 0.8885 & 0.20 & 0.8262 & 0.21 & 0.7400 & 0.23 & 0.6568 & 0.26 & 0.5829 & 0.29 & 0.5274 & 0.32 \\
\hline 0.8761 & 0.30 & 0.8200 & 0.31 & 0.7373 & 0.34 & 0.6578 & 0.39 & 0.5901 & 0.43 & 0.5412 & 0.47 \\
\hline 0.8596 & 0.40 & 0.8103 & 0.41 & 0.7329 & 0.46 & 0.6598 & 0.51 & 0.6004 & 0.56 & 0.5593 & 0.60 \\
\hline 0.8348 & 0.50 & 0.7960 & 0.52 & 0.7273 & 0.56 & 0.6632 & 0.62 & 0.6138 & 0.67 & 0.5807 & 0.71 \\
\hline 0.8012 & 0.60 & 0.7770 & 0.62 & 0.7204 & 0.67 & 0.6685 & 0.73 & 0.6306 & 0.78 & 0.6056 & 0.81 \\
\hline 0.7545 & 0.70 & 0.7517 & 0.72 & 0.7128 & 0.77 & 0.6775 & 0.82 & 0.6522 & 0.86 & 0.6345 & 0.89 \\
\hline 0.6855 & 0.80 & 0.7128 & 0.82 & 0.7049 & 0.86 & 0.6931 & 0.90 & 0.6811 & 0.93 & 0.6690 & 0.94 \\
\hline 0.5643 & 0.90 & 0.6473 & 0.91 & 0.7030 & 0.94 & 0.7256 & 0.96 & 0.7264 & 0.97 & 0.7171 & 0.98 \\
\hline 0.3208 & 1.00 & 0.4961 & 1.00 & 0.6645 & 1.00 & 0.7229 & 1.00 & 0.7339 & 1.00 & 0.7247 & 1.00 \\
\hline \multicolumn{12}{|c|}{$\mathrm{a} / \mathrm{D}=0.2$} \\
\hline 0.8495 & 0.00 & 0.7880 & 0.00 & 0.7006 & 0.00 & 0.6079 & 0.00 & 0.5250 & 0.00 & 0.4578 & 0.00 \\
\hline 0.8509 & 0.10 & 0.7872 & 0.10 & 0.7013 & 0.11 & 0.6090 & 0.12 & 0.5274 & 0.14 & 0.4616 & 0.16 \\
\hline 0.8464 & 0.20 & 0.7854 & 0.20 & 0.7020 & 0.22 & 0.6118 & 0.24 & 0.5344 & 0.28 & 0.4727 & 0.31 \\
\hline 0.8369 & 0.30 & 0.7842 & 0.31 & 0.7040 & 0.33 & 0.6176 & 0.36 & 0.5453 & 0.41 & 0.4900 & 0.45 \\
\hline 0.8236 & 0.40 & 0.7785 & 0.41 & 0.7053 & 0.43 & 0.6258 & 0.48 & 0.5602 & 0.53 & 0.5133 & 0.58 \\
\hline 0.8038 & 0.50 & 0.7698 & 0.51 & 0.7075 & 0.54 & 0.6369 & 0.59 & 0.5807 & 0.65 & 0.5420 & 0.69 \\
\hline 0.7780 & 0.60 & 0.7579 & 0.61 & 0.7093 & 0.64 & 0.6517 & 0.69 & 0.6072 & 0.75 & 0.5763 & 0.79 \\
\hline 0.7423 & 0.70 & 0.7405 & 0.71 & 0.7111 & 0.74 & 0.6717 & 0.79 & 0.6407 & 0.84 & 0.6176 & 0.87 \\
\hline 0.6900 & 0.80 & 0.7119 & 0.81 & 0.7138 & 0.83 & 0.6988 & 0.87 & 0.6838 & 0.91 & 0.6673 & 0.93 \\
\hline 0.5960 & 0.90 & 0.6548 & 0.90 & 0.7153 & 0.92 & 0.7450 & 0.95 & 0.7494 & 0.96 & 0.7375 & 0.97 \\
\hline 0.3703 & 1.00 & 0.4821 & 1.00 & 0.6704 & 1.00 & 0.7593 & 1.00 & 0.7828 & 1.00 & 0.7713 & 1.00 \\
\hline \multicolumn{12}{|c|}{$\mathrm{a} / \mathrm{D}=0.3$} \\
\hline 0.8699 & 0.00 & 0.8073 & 0.00 & 0.7097 & 0.00 & 0.5962 & 0.00 & 0.4953 & 0.00 & 0.4149 & 0.00 \\
\hline 0.8692 & 0.10 & 0.8085 & 0.10 & 0.7119 & 0.11 & 0.5995 & 0.12 & 0.4979 & 0.13 & 0.4199 & 0.15 \\
\hline 0.8648 & 0.20 & 0.8070 & 0.20 & 0.7143 & 0.21 & 0.6062 & 0.23 & 0.5074 & 0.26 & 0.4326 & 0.30 \\
\hline 0.8620 & 0.30 & 0.8045 & 0.30 & 0.7165 & 0.32 & 0.6175 & 0.35 & 0.5231 & 0.39 & 0.4554 & 0.43 \\
\hline 0.8514 & 0.40 & 0.8004 & 0.40 & 0.7230 & 0.42 & 0.6293 & 0.46 & 0.5453 & 0.51 & 0.4856 & 0.56 \\
\hline 0.8387 & 0.50 & 0.7978 & 0.50 & 0.7294 & 0.52 & 0.6464 & 0.57 & 0.5746 & 0.62 & 0.5226 & 0.67 \\
\hline 0.8172 & 0.60 & 0.7958 & 0.60 & 0.7392 & 0.62 & 0.6689 & 0.67 & 0.6107 & 0.72 & 0.5674 & 0.77 \\
\hline 0.7874 & 0.70 & 0.7831 & 0.70 & 0.7505 & 0.72 & 0.7010 & 0.77 & 0.6559 & 0.81 & 0.6205 & 0.85 \\
\hline 0.7452 & 0.80 & 0.7598 & 0.80 & 0.7625 & 0.82 & 0.7424 & 0.85 & 0.7147 & 0.89 & 0.6871 & 0.91 \\
\hline 0.6670 & 0.90 & 0.7145 & 0.90 & 0.7738 & 0.91 & 0.8048 & 0.93 & 0.8041 & 0.95 & 0.7832 & 0.97 \\
\hline 0.4628 & 1.00 & 0.5834 & 1.00 & 0.7317 & 1.00 & 0.8343 & 1.00 & 0.8574 & 1.00 & 0.8349 & 1.00 \\
\hline
\end{tabular}


Al Emran Ismail, International Journal of Emerging Trends in Engineering Research, 8(4), April 2020, 1395 - 1404

Appendix 2: Mode I stress intensity factors under tension force.

\begin{tabular}{|c|c|c|c|c|c|c|c|c|c|c|c|}
\hline \multicolumn{12}{|c|}{ Crack aspect ratios, a/b } \\
\hline \multicolumn{2}{|c|}{0.2} & \multicolumn{2}{|c|}{0.4} & \multicolumn{2}{|c|}{0.6} & \multicolumn{2}{|c|}{0.8} & \multicolumn{2}{|c|}{1.0} & \multicolumn{2}{|c|}{1.2} \\
\hline $\mathrm{F}$ & $\mathrm{x} / \mathrm{h}$ & $\mathrm{F}$ & $\mathrm{x} / \mathrm{h}$ & $\mathrm{F}$ & $\mathrm{x} / \mathrm{h}$ & $\mathrm{F}$ & $\mathrm{x} / \mathrm{h}$ & $\mathrm{F}$ & $\mathrm{x} / \mathrm{h}$ & $\mathrm{F}$ & $\mathrm{x} / \mathrm{h}$ \\
\hline \multicolumn{12}{|c|}{$\mathrm{a} / \mathrm{D}=0.1$} \\
\hline 1.0297 & 0.00 & 0.9542 & 0.00 & 0.8553 & 0.00 & 0.7591 & 0.00 & 0.6763 & 0.00 & 0.6072 & 0.00 \\
\hline 1.0283 & 0.10 & 0.9524 & 0.10 & 0.8540 & 0.12 & 0.7584 & 0.13 & 0.6770 & 0.15 & 0.6094 & 0.16 \\
\hline 1.0199 & 0.20 & 0.9471 & 0.21 & 0.8500 & 0.23 & 0.7567 & 0.26 & 0.6787 & 0.29 & 0.6156 & 0.32 \\
\hline 1.0060 & 0.30 & 0.9381 & 0.31 & 0.8435 & 0.34 & 0.7538 & 0.39 & 0.6813 & 0.43 & 0.6254 & 0.47 \\
\hline 0.9878 & 0.40 & 0.9243 & 0.41 & 0.8339 & 0.46 & 0.7503 & 0.51 & 0.6854 & 0.56 & 0.6379 & 0.60 \\
\hline 0.9602 & 0.50 & 0.9047 & 0.52 & 0.8217 & 0.56 & 0.7467 & 0.62 & 0.6918 & 0.67 & 0.6530 & 0.71 \\
\hline 0.9227 & 0.60 & 0.8791 & 0.62 & 0.8070 & 0.67 & 0.7442 & 0.73 & 0.7011 & 0.78 & 0.6705 & 0.81 \\
\hline 0.8706 & 0.70 & 0.8459 & 0.72 & 0.7903 & 0.77 & 0.7446 & 0.82 & 0.7146 & 0.86 & 0.6913 & 0.89 \\
\hline 0.7931 & 0.80 & 0.7971 & 0.82 & 0.7723 & 0.86 & 0.7508 & 0.90 & 0.7348 & 0.93 & 0.7178 & 0.94 \\
\hline 0.6559 & 0.90 & 0.7188 & 0.91 & 0.7605 & 0.94 & 0.7748 & 0.96 & 0.7726 & 0.97 & 0.7587 & 0.98 \\
\hline 0.3773 & 1.00 & 0.5498 & 1.00 & 0.7130 & 1.00 & 0.7651 & 1.00 & 0.7740 & 1.00 & 0.7602 & 1.00 \\
\hline \multicolumn{12}{|c|}{$\mathrm{a} / \mathrm{D}=0.2$} \\
\hline 1.1384 & 0.00 & 1.0568 & 0.00 & 0.9438 & 0.00 & 0.8255 & 0.00 & 0.7235 & 0.00 & 0.6400 & 0.00 \\
\hline 1.1381 & 0.10 & 1.0533 & 0.10 & 0.9420 & 0.11 & 0.8247 & 0.12 & 0.7243 & 0.14 & 0.6422 & 0.16 \\
\hline 1.1316 & 0.20 & 1.0505 & 0.20 & 0.9381 & 0.22 & 0.8247 & 0.24 & 0.7274 & 0.28 & 0.6494 & 0.31 \\
\hline 1.1195 & 0.30 & 1.0453 & 0.31 & 0.9360 & 0.33 & 0.8249 & 0.36 & 0.7311 & 0.41 & 0.6604 & 0.45 \\
\hline 1.1019 & 0.40 & 1.0330 & 0.41 & 0.9317 & 0.43 & 0.8244 & 0.48 & 0.7367 & 0.53 & 0.6747 & 0.58 \\
\hline 1.0825 & 0.50 & 1.0193 & 0.51 & 0.9244 & 0.54 & 0.8238 & 0.59 & 0.7460 & 0.65 & 0.6928 & 0.69 \\
\hline 1.0532 & 0.60 & 1.0006 & 0.61 & 0.9145 & 0.64 & 0.8263 & 0.69 & 0.7600 & 0.75 & 0.7146 & 0.79 \\
\hline 1.0092 & 0.70 & 0.9737 & 0.71 & 0.9047 & 0.74 & 0.8333 & 0.79 & 0.7798 & 0.84 & 0.7421 & 0.87 \\
\hline 0.9440 & 0.80 & 0.9324 & 0.81 & 0.8934 & 0.83 & 0.8459 & 0.87 & 0.8094 & 0.91 & 0.7782 & 0.93 \\
\hline 0.8241 & 0.90 & 0.8548 & 0.90 & 0.8806 & 0.92 & 0.8803 & 0.95 & 0.8643 & 0.96 & 0.8374 & 0.97 \\
\hline 0.5225 & 1.00 & 0.6328 & 1.00 & 0.8172 & 1.00 & 0.8843 & 1.00 & 0.8887 & 1.00 & 0.8622 & 1.00 \\
\hline \multicolumn{12}{|c|}{$\mathrm{a} / \mathrm{D}=0.3$} \\
\hline 1.3666 & 0.00 & 1.2671 & 0.00 & 1.1246 & 0.00 & 0.9587 & 0.00 & 0.8142 & 0.00 & 0.7002 & 0.00 \\
\hline 1.3617 & 0.10 & 1.2674 & 0.10 & 1.1187 & 0.11 & 0.9569 & 0.12 & 0.8153 & 0.13 & 0.7040 & 0.15 \\
\hline 1.3561 & 0.20 & 1.2637 & 0.20 & 1.1199 & 0.21 & 0.9601 & 0.23 & 0.8201 & 0.26 & 0.7104 & 0.30 \\
\hline 1.3550 & 0.30 & 1.2590 & 0.30 & 1.1215 & 0.32 & 0.9668 & 0.35 & 0.8290 & 0.39 & 0.7267 & 0.43 \\
\hline 1.3437 & 0.40 & 1.2537 & 0.40 & 1.1209 & 0.42 & 0.9696 & 0.46 & 0.8401 & 0.51 & 0.7482 & 0.56 \\
\hline 1.3273 & 0.50 & 1.2473 & 0.50 & 1.1179 & 0.52 & 0.9764 & 0.57 & 0.8565 & 0.62 & 0.7687 & 0.67 \\
\hline 1.2982 & 0.60 & 1.2354 & 0.60 & 1.1187 & 0.62 & 0.9885 & 0.67 & 0.8795 & 0.72 & 0.7984 & 0.77 \\
\hline 1.2610 & 0.70 & 1.2105 & 0.70 & 1.1172 & 0.72 & 1.0056 & 0.77 & 0.9109 & 0.81 & 0.8373 & 0.85 \\
\hline 1.2014 & 0.80 & 1.1759 & 0.80 & 1.1157 & 0.82 & 1.0331 & 0.85 & 0.9577 & 0.89 & 0.8908 & 0.91 \\
\hline 1.0886 & 0.90 & 1.1070 & 0.90 & 1.1143 & 0.91 & 1.0902 & 0.93 & 1.0403 & 0.95 & 0.9793 & 0.97 \\
\hline 0.7749 & 1.00 & 0.9119 & 1.00 & 1.0481 & 1.00 & 1.1106 & 1.00 & 1.0859 & 1.00 & 1.0201 & 1.00 \\
\hline
\end{tabular}


Al Emran Ismail, International Journal of Emerging Trends in Engineering Research, 8(4), April 2020, 1395 - 1404

Appendix 3: Mode II stress intensity factors under torsion moment.

\begin{tabular}{|c|c|c|c|c|c|c|c|c|c|c|c|}
\hline \multicolumn{12}{|c|}{ Crack aspect ratios, a/b } \\
\hline \multicolumn{2}{|c|}{0.2} & \multicolumn{2}{|c|}{0.4} & \multicolumn{2}{|c|}{0.6} & \multicolumn{2}{|c|}{0.8} & \multicolumn{2}{|c|}{1.0} & \multicolumn{2}{|c|}{1.2} \\
\hline $\mathrm{F}$ & $\mathrm{x} / \mathrm{h}$ & $\mathrm{F}$ & $\mathrm{x} / \mathrm{h}$ & $\mathrm{F}$ & $\mathrm{x} / \mathrm{h}$ & $\mathrm{F}$ & $\mathrm{x} / \mathrm{h}$ & $\mathrm{F}$ & $\mathrm{x} / \mathrm{h}$ & $\mathrm{F}$ & $\mathrm{x} / \mathrm{h}$ \\
\hline \multicolumn{12}{|c|}{$\mathrm{a} / \mathrm{D}=0.1$} \\
\hline 0.0000 & 0.00 & 0.0001 & 0.00 & 0.0001 & 0.00 & 0.0000 & 0.00 & -0.0001 & 0.00 & 0.0002 & 0.00 \\
\hline-0.0575 & 0.10 & -0.0649 & 0.10 & -0.0758 & 0.12 & -0.0904 & 0.13 & -0.1054 & 0.15 & -0.1207 & 0.16 \\
\hline-0.1146 & 0.20 & -0.1295 & 0.21 & -0.1515 & 0.23 & -0.1804 & 0.26 & -0.2087 & 0.29 & -0.2358 & 0.32 \\
\hline-0.1702 & 0.30 & -0.1935 & 0.31 & -0.2273 & 0.34 & -0.2691 & 0.39 & -0.3078 & 0.43 & -0.3407 & 0.47 \\
\hline-0.2229 & 0.40 & -0.2563 & 0.41 & -0.3027 & 0.46 & -0.3560 & 0.51 & -0.4004 & 0.56 & -0.4325 & 0.60 \\
\hline-0.2715 & 0.50 & -0.3172 & 0.52 & -0.3778 & 0.56 & -0.4396 & 0.62 & -0.4844 & 0.67 & -0.5099 & 0.71 \\
\hline-0.3143 & 0.60 & -0.3755 & 0.62 & -0.4521 & 0.67 & -0.5193 & 0.73 & -0.5581 & 0.78 & -0.5738 & 0.81 \\
\hline-0.3487 & 0.70 & -0.4296 & 0.72 & -0.5251 & 0.77 & -0.5928 & 0.82 & -0.6208 & 0.86 & -0.6253 & 0.89 \\
\hline-0.3686 & 0.80 & -0.4762 & 0.82 & -0.5956 & 0.86 & -0.6584 & 0.90 & -0.6733 & 0.93 & -0.6672 & 0.94 \\
\hline-0.3573 & 0.90 & -0.5152 & 0.91 & -0.6782 & 0.94 & -0.7308 & 0.96 & -0.7312 & 0.97 & -0.7138 & 0.98 \\
\hline-0.4428 & 1.00 & -0.6292 & 1.00 & -0.7716 & 1.00 & -0.7923 & 1.00 & -0.7794 & 1.00 & -0.7521 & 1.00 \\
\hline \multicolumn{12}{|c|}{$\mathrm{a} / \mathrm{D}=0.2$} \\
\hline 0.0000 & 0.00 & 0.0000 & 0.00 & 0.0001 & 0.00 & 0.0001 & 0.00 & -0.0001 & 0.00 & 0.0000 & 0.00 \\
\hline-0.0732 & 0.10 & -0.0778 & 0.10 & -0.0838 & 0.11 & -0.0923 & 0.12 & -0.1022 & 0.14 & -0.1123 & 0.16 \\
\hline-0.1460 & 0.20 & -0.1546 & 0.20 & -0.1676 & 0.22 & -0.1840 & 0.24 & -0.2026 & 0.28 & -0.2202 & 0.31 \\
\hline-0.2165 & 0.30 & -0.2309 & 0.31 & -0.2505 & 0.33 & -0.2747 & 0.36 & -0.2996 & 0.41 & -0.3201 & 0.45 \\
\hline-0.2850 & 0.40 & -0.3054 & 0.41 & -0.3319 & 0.43 & -0.3632 & 0.48 & -0.3911 & 0.53 & -0.4101 & 0.58 \\
\hline-0.3493 & 0.50 & -0.3766 & 0.51 & -0.4124 & 0.54 & -0.4495 & 0.59 & -0.4768 & 0.65 & -0.4893 & 0.69 \\
\hline-0.4088 & 0.60 & -0.4442 & 0.61 & -0.4900 & 0.64 & -0.5323 & 0.69 & -0.5549 & 0.75 & -0.5588 & 0.79 \\
\hline-0.4608 & 0.70 & -0.5065 & 0.71 & -0.5657 & 0.74 & -0.6108 & 0.79 & -0.6255 & 0.84 & -0.6201 & 0.87 \\
\hline-0.5012 & 0.80 & -0.5600 & 0.81 & -0.6397 & 0.83 & -0.6868 & 0.87 & -0.6920 & 0.91 & -0.6768 & 0.93 \\
\hline-0.5189 & 0.90 & -0.6037 & 0.90 & -0.7251 & 0.92 & -0.7808 & 0.95 & -0.7765 & 0.96 & -0.7492 & 0.97 \\
\hline-0.6020 & 1.00 & -0.7015 & 1.00 & -0.8369 & 1.00 & -0.8545 & 1.00 & -0.8312 & 1.00 & -0.7932 & 1.00 \\
\hline \multicolumn{12}{|c|}{$\mathrm{a} / \mathrm{D}=0.3$} \\
\hline 0.0000 & 0.00 & 0.0007 & 0.00 & 0.0002 & 0.00 & -0.0001 & 0.00 & -0.0001 & 0.00 & 0.0000 & 0.00 \\
\hline-0.0874 & 0.10 & -0.0900 & 0.10 & -0.0926 & 0.11 & -0.0965 & 0.12 & -0.1011 & 0.13 & -0.1055 & 0.15 \\
\hline-0.1749 & 0.20 & -0.1798 & 0.20 & -0.1857 & 0.21 & -0.1924 & 0.23 & -0.2007 & 0.26 & -0.2074 & 0.30 \\
\hline-0.2612 & 0.30 & -0.2686 & 0.30 & -0.2772 & 0.32 & -0.2874 & 0.35 & -0.2976 & 0.39 & -0.3043 & 0.43 \\
\hline-0.3444 & 0.40 & -0.3543 & 0.40 & -0.3675 & 0.42 & -0.3808 & 0.46 & -0.3912 & 0.51 & -0.3945 & 0.56 \\
\hline-0.4255 & 0.50 & -0.4404 & 0.50 & -0.4561 & 0.52 & -0.4716 & 0.57 & -0.4805 & 0.62 & -0.4768 & 0.67 \\
\hline-0.5026 & 0.60 & -0.5245 & 0.60 & -0.5441 & 0.62 & -0.5599 & 0.67 & -0.5642 & 0.72 & -0.5531 & 0.77 \\
\hline-0.5750 & 0.70 & -0.6012 & 0.70 & -0.6325 & 0.72 & -0.6508 & 0.77 & -0.6457 & 0.81 & -0.6253 & 0.85 \\
\hline-0.6411 & 0.80 & -0.6760 & 0.80 & -0.7213 & 0.82 & -0.7446 & 0.85 & -0.7294 & 0.89 & -0.6994 & 0.91 \\
\hline-0.6992 & 0.90 & -0.7519 & 0.90 & -0.8312 & 0.91 & -0.8677 & 0.93 & -0.8449 & 0.95 & -0.8014 & 0.97 \\
\hline-0.8159 & 1.00 & -0.9002 & 1.00 & -0.9552 & 1.00 & -0.9473 & 1.00 & -0.9005 & 1.00 & -0.8392 & 1.00 \\
\hline
\end{tabular}


Al Emran Ismail, International Journal of Emerging Trends in Engineering Research, 8(4), April 2020, 1395 - 1404

Appendix 4: Mode III stress intensity factors under torsion moment.

\begin{tabular}{|c|c|c|c|c|c|c|c|c|c|c|c|}
\hline \multicolumn{12}{|c|}{ Crack aspect ratios, $\mathrm{a} / \mathrm{b}$} \\
\hline \multicolumn{2}{|c|}{0.2} & \multicolumn{2}{|c|}{0.4} & \multicolumn{2}{|c|}{0.6} & \multicolumn{2}{|c|}{0.8} & \multicolumn{2}{|c|}{1.0} & \multicolumn{2}{|c|}{1.2} \\
\hline $\mathrm{F}$ & $\mathrm{x} / \mathrm{h}$ & $\mathrm{F}$ & $\mathrm{x} / \mathrm{h}$ & $\mathrm{F}$ & $\mathrm{x} / \mathrm{h}$ & $\mathrm{F}$ & $\mathrm{x} / \mathrm{h}$ & $\mathrm{F}$ & $\mathrm{x} / \mathrm{h}$ & $\mathrm{F}$ & $\mathrm{x} / \mathrm{h}$ \\
\hline \multicolumn{12}{|c|}{$\mathrm{a} / \mathrm{D}=0.1$} \\
\hline 0.7816 & 0.00 & 0.7114 & 0.00 & 0.6217 & 0.00 & 0.5367 & 0.00 & 0.4641 & 0.00 & 0.4073 & 0.00 \\
\hline 0.7801 & 0.10 & 0.7092 & 0.10 & 0.6189 & 0.12 & 0.5330 & 0.13 & 0.4592 & 0.15 & 0.4006 & 0.16 \\
\hline 0.7740 & 0.20 & 0.7030 & 0.21 & 0.6107 & 0.23 & 0.5216 & 0.26 & 0.4443 & 0.29 & 0.3812 & 0.32 \\
\hline 0.7644 & 0.30 & 0.6925 & 0.31 & 0.5965 & 0.34 & 0.5023 & 0.39 & 0.4200 & 0.43 & 0.3516 & 0.47 \\
\hline 0.7507 & 0.40 & 0.6772 & 0.41 & 0.5758 & 0.46 & 0.4748 & 0.51 & 0.3869 & 0.56 & 0.3147 & 0.60 \\
\hline 0.7315 & 0.50 & 0.6561 & 0.52 & 0.5478 & 0.56 & 0.4388 & 0.62 & 0.3464 & 0.67 & 0.2738 & 0.71 \\
\hline 0.7050 & 0.60 & 0.6286 & 0.62 & 0.5112 & 0.67 & 0.3941 & 0.73 & 0.3005 & 0.78 & 0.2321 & 0.81 \\
\hline 0.6694 & 0.70 & 0.5936 & 0.72 & 0.4648 & 0.77 & 0.3415 & 0.82 & 0.2523 & 0.86 & 0.1929 & 0.89 \\
\hline 0.6183 & 0.80 & 0.5475 & 0.82 & 0.4077 & 0.86 & 0.2843 & 0.90 & 0.2076 & 0.93 & 0.1615 & 0.94 \\
\hline 0.5301 & 0.90 & 0.4818 & 0.91 & 0.3343 & 0.94 & 0.2252 & 0.96 & 0.1728 & 0.97 & 0.1455 & 0.98 \\
\hline 0.0681 & 1.00 & 0.1543 & 1.00 & 0.2667 & 1.00 & 0.3301 & 1.00 & 0.3507 & 1.00 & 0.3411 & 1.00 \\
\hline \multicolumn{12}{|c|}{$\mathrm{a} / \mathrm{D}=0.2$} \\
\hline 0.6979 & 0.00 & 0.6393 & 0.00 & 0.5568 & 0.00 & 0.4719 & 0.00 & 0.3994 & 0.00 & 0.3428 & 0.00 \\
\hline 0.6973 & 0.10 & 0.6379 & 0.10 & 0.5549 & 0.11 & 0.4687 & 0.12 & 0.3951 & 0.14 & 0.3369 & 0.16 \\
\hline 0.6947 & 0.20 & 0.6342 & 0.20 & 0.5486 & 0.22 & 0.4592 & 0.24 & 0.3819 & 0.28 & 0.3197 & 0.31 \\
\hline 0.6898 & 0.30 & 0.6282 & 0.31 & 0.5383 & 0.33 & 0.4434 & 0.36 & 0.3605 & 0.41 & 0.2933 & 0.45 \\
\hline 0.6821 & 0.40 & 0.6184 & 0.41 & 0.5231 & 0.43 & 0.4210 & 0.48 & 0.3315 & 0.53 & 0.2603 & 0.58 \\
\hline 0.6721 & 0.50 & 0.6056 & 0.51 & 0.5028 & 0.54 & 0.3918 & 0.59 & 0.2960 & 0.65 & 0.2234 & 0.69 \\
\hline 0.6581 & 0.60 & 0.5896 & 0.61 & 0.4777 & 0.64 & 0.3560 & 0.69 & 0.2561 & 0.75 & 0.1856 & 0.79 \\
\hline 0.6402 & 0.70 & 0.5701 & 0.71 & 0.4474 & 0.74 & 0.3143 & 0.79 & 0.2140 & 0.84 & 0.1496 & 0.87 \\
\hline 0.6148 & 0.80 & 0.5460 & 0.81 & 0.4128 & 0.83 & 0.2705 & 0.87 & 0.1752 & 0.91 & 0.1211 & 0.93 \\
\hline 0.5696 & 0.90 & 0.5141 & 0.90 & 0.3746 & 0.92 & 0.2267 & 0.95 & 0.1451 & 0.96 & 0.1065 & 0.97 \\
\hline 0.1276 & 1.00 & 0.1951 & 1.00 & 0.3065 & 1.00 & 0.3693 & 1.00 & 0.3575 & 1.00 & 0.3394 & 1.00 \\
\hline \multicolumn{12}{|c|}{$\mathrm{a} / \mathrm{D}=0.3$} \\
\hline 0.6465 & 0.00 & 0.5917 & 0.00 & 0.5102 & 0.00 & 0.4203 & 0.00 & 0.3429 & 0.00 & 0.2833 & 0.00 \\
\hline 0.6461 & 0.10 & 0.5913 & 0.10 & 0.5090 & 0.11 & 0.4178 & 0.12 & 0.3389 & 0.13 & 0.2779 & 0.15 \\
\hline 0.6449 & 0.20 & 0.5893 & 0.20 & 0.5044 & 0.21 & 0.4102 & 0.23 & 0.3273 & 0.26 & 0.2625 & 0.30 \\
\hline 0.6441 & 0.30 & 0.5853 & 0.30 & 0.4964 & 0.32 & 0.3974 & 0.35 & 0.3086 & 0.39 & 0.2392 & 0.43 \\
\hline 0.6421 & 0.40 & 0.5793 & 0.40 & 0.4850 & 0.42 & 0.3787 & 0.46 & 0.2832 & 0.51 & 0.2093 & 0.56 \\
\hline 0.6387 & 0.50 & 0.5735 & 0.50 & 0.4703 & 0.52 & 0.3542 & 0.57 & 0.2520 & 0.62 & 0.1761 & 0.67 \\
\hline 0.6339 & 0.60 & 0.5672 & 0.60 & 0.4548 & 0.62 & 0.3260 & 0.67 & 0.2166 & 0.72 & 0.1414 & 0.77 \\
\hline 0.6282 & 0.70 & 0.5581 & 0.70 & 0.4359 & 0.72 & 0.2932 & 0.77 & 0.1790 & 0.81 & 0.1075 & 0.85 \\
\hline 0.6210 & 0.80 & 0.5491 & 0.80 & 0.4165 & 0.82 & 0.2600 & 0.85 & 0.1440 & 0.89 & 0.0801 & 0.91 \\
\hline 0.6084 & 0.90 & 0.5427 & 0.90 & 0.4028 & 0.91 & 0.2287 & 0.93 & 0.1153 & 0.95 & 0.0636 & 0.97 \\
\hline 0.2591 & 1.00 & 0.3306 & 1.00 & 0.4210 & 1.00 & 0.4507 & 1.00 & 0.4158 & 1.00 & 0.3710 & 1.00 \\
\hline
\end{tabular}

